\title{
Band Tunable CdSe Quantum Dot-Doped Metals for Quantum Dot-Sensitized Solar Cell Application
}

\author{
Dang Huu Phuc $\mathbb{D}^{1,2}$ and Ha Thanh Tung $\mathbb{D}^{3}$ \\ ${ }^{1}$ Laboratory of Applied Physics, Advanced Institute of Materials Science, Ton Duc Thang University, Ho Chi Minh City, Vietnam \\ ${ }^{2}$ Faculty of Applied Sciences, Ton Duc Thang University, Ho Chi Minh City, Vietnam \\ ${ }^{3}$ Institute of Research and Development, Duy Tan University, Da Nang, Vietnam
}

Correspondence should be addressed to Dang Huu Phuc; danghuuphuc@tdt.edu.vn and Ha Thanh Tung; httung@dthu.edu.vn

Received 17 November 2018; Accepted 25 December 2018; Published 25 February 2019

Guest Editor: Wei Wei

Copyright @ 2019 Dang Huu Phuc and Ha Thanh Tung. This is an open access article distributed under the Creative Commons Attribution License, which permits unrestricted use, distribution, and reproduction in any medium, provided the original work is properly cited.

\begin{abstract}
Quantum dots are drawing great attention as a material for the next-generation solar cells because of the high absorption coefficient, tunable band gap, and multiple exciton generation effect. In search of the viable way to enhance the power conversion efficiency of quantum dot-sensitized solar cells, we have succeeded in preparing the quantum dot solar cells with high efficiency based on CdSe:X $\left(\mathrm{Mn}^{2+}\right.$ or $\left.\mathrm{Cu}^{2+}\right)$ nanocrystal by successive ionic layer absorption and reaction. The morphological observation and crystalline structure of photoanode were characterized by field-emission scanning electron microscopy, X-ray diffraction, and the EDX spectra. In addition, the electrochemical performance of photoelectrode was studied by the electrochemical impedance spectra. As a result, we have succeeded in designing QDSSCs with a high efficiency of $4.3 \%$. Moreover, the optical properties, the direct optical energy gap, and both the conduction band and the valence band levels of the compositional CdSe:X were estimated by the theory of Tauc and discussed details. This theory is useful for us to understand the alignment energy structure of the compositions in electrodes, in particular, the conduction band and valence band levels of CdSe:X nanoparticles.
\end{abstract}

\section{Introduction}

In recent years, inorganic semiconductor materials, which are also called Quantum Dots (QDs), have emerged as a powerful light-absorbing material that generates electrons for the quantum dot-sensitized solar cell (QDSSC) application. Various QDs were applied in the QDSSCs such as CdS, CdSe [1], PbS, PbSe [2, 3], and InP [1]. These had a number of advantages over dye molecules because the band gap could be controlled through particle size, modification [4], the high optical absorption coefficient [5], and generating several $\mathrm{e}-\mathrm{h}^{+}$pairs as absorbing photons [6]. So far, QDSSCs have still low optical conversion efficiency compared to dye-sensitized solar cells [7-11].

There are now a number of ways to improve performance of QDSSCs such as QDSSCs based on the CdS/CdSe combination synthesized by chemical bath deposition methods and successive ionic layer absorption and reaction (SILAR) adsorbed directly onto $\mathrm{TiO}_{2}$ nanoparticles $[12,13]$.
The improved performance was also achieved on core-shell QDs. Yu et al. reported the fabrication results on the $\mathrm{CdS} / \mathrm{CdSe}$ core-shell system, resulting in higher current density, voltage, and performance than single QDs [13]. $\mathrm{Yu}$ said that the improved performance was done because of the reduced recombination processes at the surface trapping states of QDs and the increased electron mobility to $\mathrm{TiO}_{2}$ nanoparticles. In addition, the combination of electrons and holes in the contact surfaces and in semiconductor oxides such as $\mathrm{TiO}_{2}$ and $\mathrm{ZnO}$ causes the reduction in performance of QDSSCs. To reduce the recombination processes, Jung and colleagues coated CdS QDs with a $\mathrm{ZnS}$ layer to protect QDs from the electrolyte [14-16]. This result was also confirmed in the QDSSCs based on $\mathrm{PbS}$ QDs with a CdS protection layer [17]. There were many methods that can reduce recombination in devices, but the most common method of surface treatment was used. Surface treatment means protection of QDs, which helped stabilize QDs in an electrolyte solution $[18,19]$. 
Today, CdSe QDs are widely used by scientists in QDSSCs because of their easy manufacture, low cost, and high stability. However, their resistance is high and their $\mathrm{CB}$ energy is lower than that of $\mathrm{TiO}_{2}$ in the bulk material. These results do not facilitate the shift of electrons from CdSe QDs to the $\mathrm{TiO}_{2}$ film. By doping metal ions into QDs such as $\mathrm{Cu}$ [6], In [20], Co [21], Mn [22, 23], $\mathrm{Hg}$ [24], $\mathrm{Eu}[25,26], \mathrm{La}[27]$, and $\mathrm{Mg}[28]$, the electrical and optical properties of photoanode can be improved by the boosting absorption of photons of QDSSCs.

As far as reasons are concerned, QDSSCs based on X ions doped on CdSe nanoparticles with the different compositions of the $\mathrm{Mn}^{2+}(x$ between $0 \%$ and $40 \%)$ and the $\mathrm{Cu}^{2+}(y$ from $0 \%$ to $0.5 \%$ ) by SILAR were illustrated. Moreover, the significant effects of X dopant on optical, physical, chemical, and photovoltaic properties of QDSSCs can be studied by the UV-Vis spectra and Tauc equation, which can determine the $E_{g}, \mathrm{CB}$, and $\mathrm{VB}$ positions of $\mathrm{X}$ ions doped on pure CdSe nanoparticles. This theory is useful for us to understand the alignment energy structure of the compositions in electrodes, in particular, CB and VB levels of CdS, CdSe:X nanoparticles. As a result, there is a rise or a drop of the $\mathrm{CB}$ and the VB levels when $\mathrm{X}$ content was changed. Correspondingly, the electrochemical impedance spectra were carried out to determine dynamic resistances in QDSSCs.

\section{Experiment}

In this experiment, $\mathrm{TiO}_{2} / \mathrm{CdS}$ and $\mathrm{TiO}_{2} / \mathrm{CdS} / \mathrm{CdSe}: \mathrm{Cu}^{2+}$ were synthesized similar to Ref [29]. In Ref [29], the thickness of $\mathrm{TiO}_{2} / \mathrm{CdS} / \mathrm{CdSe}: \mathrm{Cu}^{2+}$ was investigated to get the optimization. However, in this paper, we investigated the effect of $\mathrm{Cu}^{2+}$ molar concentrations as doping it into CdSe nanoparticle. Besides, we also prepared QDSSCs based on $\mathrm{Mn}^{2+}$ ion-doped CdSe nanoparticle and compared with that of QDSSCs based on $\mathrm{TiO}_{2} / \mathrm{CdS} / \mathrm{CdSe}: \mathrm{Cu}^{2+}$ photoanode.

2.1. $\mathrm{TiO}_{2}$ and $\mathrm{TiO}_{2} / \mathrm{CdS}$ Films Were Prepared As Follows Ref [29]. Briefly, a fluorine-doped tin oxide (FTO) glass substrate with sheet resistance $7 \Omega \mathrm{sq}^{-2}$ was used for the photoanode and the counter electrode. First, the FTO substrate was cleaned with ethanol for $30 \mathrm{~min}$ by ultrasonic, followed by deionized (DI) water for $15 \mathrm{~min}$. The nanoporous $\mathrm{TiO}_{2}$ film was made on the well-cleaned substrate by the print method followed by sintering at $500^{\circ} \mathrm{C}$ for 30 min. $\mathrm{TiO}_{2} / \mathrm{CdS}$ film: $\mathrm{TiO}_{2}$ films were dipped into a $\mathrm{Cd}\left(\mathrm{CH}_{3} \mathrm{COO}\right)_{2} \cdot 2 \mathrm{H}_{2} \mathrm{O}$ ethanol solution for $5 \mathrm{~min}$, rinsed with ethanol, and dried, then successively dipped into a $\mathrm{Na}_{2} \mathrm{~S} \cdot 9 \mathrm{H}_{2} \mathrm{O}$ methanol solution for another $5 \mathrm{~min}$, rinsed with methanol, and dried. The two-step dipping procedure was termed as one SILAR cycle. The process was repeated three times, and the obtained $\mathrm{TiO}_{2}$ film decorated with CdS QDs was named as the $\mathrm{TiO}_{2} / \mathrm{CdS}$ film [30].

2.2. $\mathrm{A} \mathrm{TiO}_{2} / \mathrm{CdS} / \mathrm{CdSe}: \mathrm{Mn}^{2+}$ Film. Similarly, the Mn doped on CdSe QDs was attached to the $\mathrm{TiO}_{2} / \mathrm{CdS}$ film using SILAR. $0.740304 \mathrm{~g} \mathrm{Cd}\left(\mathrm{NO}_{3}\right)_{2} \cdot 2 \mathrm{H}_{2} \mathrm{O}$ and $0.47054 \mathrm{~g} \mathrm{Mn}\left(\mathrm{CH}_{3} \mathrm{COO}\right)_{2}$. $2 \mathrm{H}_{2} \mathrm{O}$ were dissolved in $30 \mathrm{ml}$ ethanol and DI water with ratio

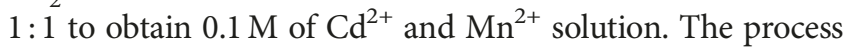

involved subsequent immersions of the $\mathrm{TiO}_{2} / \mathrm{CdS}$ film in a solution of $0.1 \mathrm{M}$ of $\mathrm{Cd}^{2+}$ and $\mathrm{Mn}^{2+}$ solution for $5 \mathrm{~min}$ and then rinsed with ethanol. It then was immersed in $0.3 \mathrm{M}$ of $\mathrm{Se}^{2-}$ solution for $5 \mathrm{~min}$ at $50^{\circ} \mathrm{C}$ and rinsed with DI water. To accommodate the doping of $\mathrm{Mn}^{2+}$ ion, relevant molar concentrations of $0.1 \mathrm{mM}, 0.2 \mathrm{mM}, 0.3 \mathrm{mM}$, $0.4 \mathrm{mM}$, and $0.5 \mathrm{mM}$ of $\mathrm{Mn}\left(\mathrm{CH}_{3} \mathrm{COO}\right)_{2} \cdot 2 \mathrm{H}_{2} \mathrm{O}$ were mixed with $\mathrm{Cd}\left(\mathrm{CH}_{3} \mathrm{COO}\right)_{2} \cdot 2 \mathrm{H}_{2} \mathrm{O}$ anion source. The process was repeated 3 times and the obtained $\mathrm{TiO}_{2} / \mathrm{CdS}$ film decorated with CdS/Mn-CdSe multilayers.

2.3. $\mathrm{A} \mathrm{TiO}_{2} / \mathrm{CdS} / \mathrm{CdSe}: \mathrm{Cu}^{2+}$ Film. Preparation of $\mathrm{TiO}_{2} / \mathrm{CdS} / \mathrm{CdSe}$ : $\mathrm{Cu}^{2+}$ photoanodes: briefly, the $\mathrm{TiO} 2 / \mathrm{CdS}$ layers were immersed into $\mathrm{Cd}^{2+}$ and $\mathrm{Cu}^{2+}$ ionized solution (molar concentrations of $0.1 \mathrm{mM}, 0.2 \mathrm{mM}, 0.3 \mathrm{mM}, 0.4 \mathrm{mM}$, and $0.5 \mathrm{mM}$ of $\mathrm{Cu}\left(\mathrm{NO}_{3}\right)_{2} \cdot 3 \mathrm{H}_{2} \mathrm{O}$ were mixed with $\mathrm{Cd}\left(\mathrm{CH}_{3} \mathrm{COO}\right)_{2} \cdot 2 \mathrm{H}_{2} \mathrm{O}$ anion source) for $5 \mathrm{~min}$ at room temperature, then rinsed with ethanol to remove excess precursors and dried. The films were next dipped into $\mathrm{Se}^{2-}$ solution for $5 \mathrm{~min}$ at room temperature followed by rinsing with methanol and drying. This cycle was repeated 3 times [30]. The polysulfide electrolyte and $\mathrm{Cu}_{2} \mathrm{~S}$ counter electrode were followed Ref [30].

2.4. Characterization. Field-effect scanning electron microscope (FESEM, 7401F) of Ho Chi Minh City Institute of Physics was used to investigate the surface morphology and composition of photoanode using the voltage of $10 \mathrm{kV}$. The UV-Vis spectra were characterized by the JASCO V-670 device of Applied Physical Chemistry Lab of University of Science, Vietnam National University-Ho Chi Minh City. The crystal structure was analyzed using an X-ray diffractometer (Philips, PANalytical X'Pert, CuK_radiation) and photocurrent-voltage measurements were performed on a Keithley 2400 source meter using simulated AM 1.5 sunlight with an output power of $100 \mathrm{~mW} \times \mathrm{cm}^{-2}$ produced by a solar simulator (Solarena, Sweden). The electrochemical impedance spectroscopy (EIS) was carried out with the use of an impedance analyzer (ZAHNER CIMPS).

\section{Results and Discussion}

Figures 1 (a) and $1(\mathrm{~d})$ are FESEM images of $\mathrm{TiO}_{2} / \mathrm{CdS} / \mathrm{CdSe}$ : $\mathrm{Mn}^{2+}$ and $\mathrm{TiO}_{2} / \mathrm{CdS} / \mathrm{CdSe}: \mathrm{Cu}^{2+}$ photoanodes with $20 \%$ and $0.3 \%$ doping concentration, respectively. The highly porous nearly spherical-shaped $\mathrm{TiO}_{2}$ nanoparticles can be observed very clearly from Figures 1 (a) and 1(d) with an average size of approximately $70 \mathrm{~nm}$. We can clearly see each layer of film, thickness of the FTO layer about $0.563 \mathrm{~nm}$. The thickness of $\mathrm{TiO}_{2} / \mathrm{CdS} / \mathrm{CdSe}: \mathrm{Mn}^{2+}$ and $\mathrm{TiO}_{2} / \mathrm{CdS} / \mathrm{CdSe}: \mathrm{Cu}^{2+}$ photoanodes is approximately $12.056 \mu \mathrm{m}$ and $12.675 \mu \mathrm{m}$, respectively. However, we did not observe both CdSe:Mn ${ }^{2+}$ and CdSe: $\mathrm{Cu}^{2+}$ nanoparticles in the film because of their very small size. They can be filled in the space between the $\mathrm{TiO}_{2}$ nanoparticles and absorbed onto the $\mathrm{TiO}_{2}$ surface.

The compositional EDX analysis of the CdSe:X is shown in Figures 1(c) and 1(f), which confirm the presence of $\mathrm{Mn}^{2+}$ and $\mathrm{Cu}^{2+}$ dopant in photoanodes. As can be seen from Figures $1(\mathrm{~g})$ and $1(\mathrm{~h})$, they are the same structures of $\mathrm{TiO}_{2}$, 


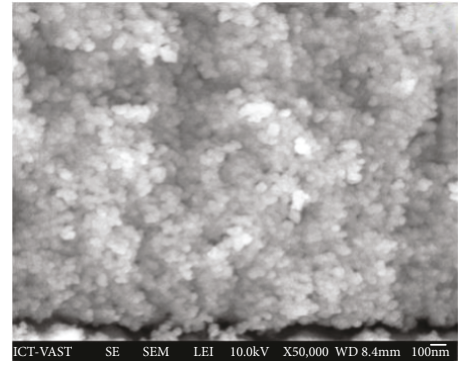

(a)

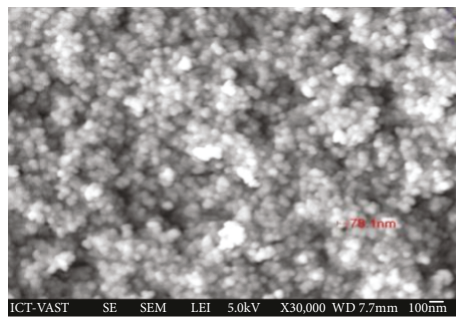

(d)

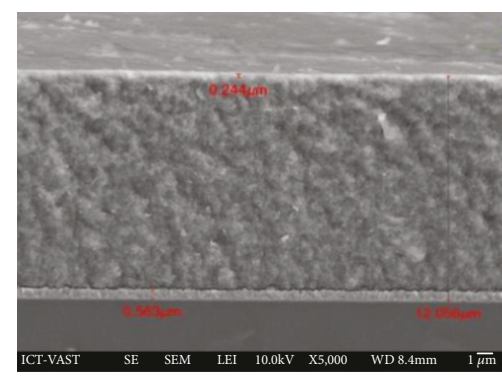

(b)

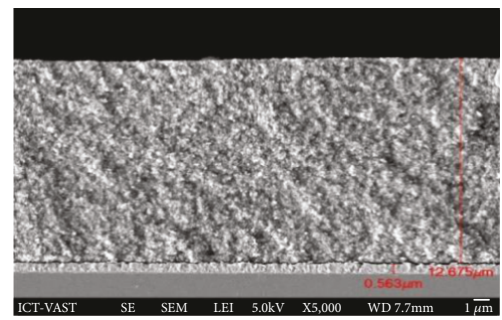

(e)

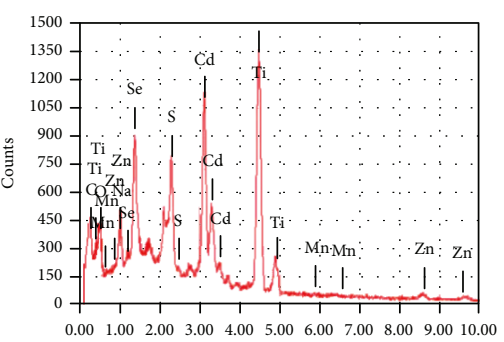

$\mathrm{keV}$

(c)

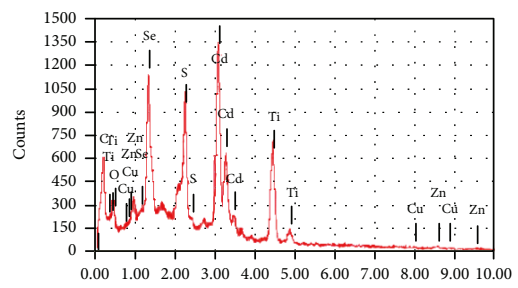

(f)

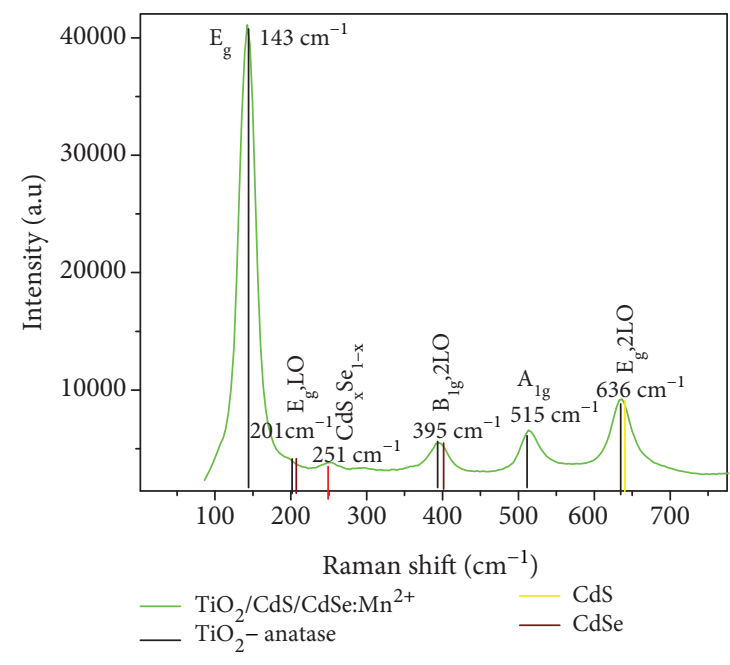

(g)

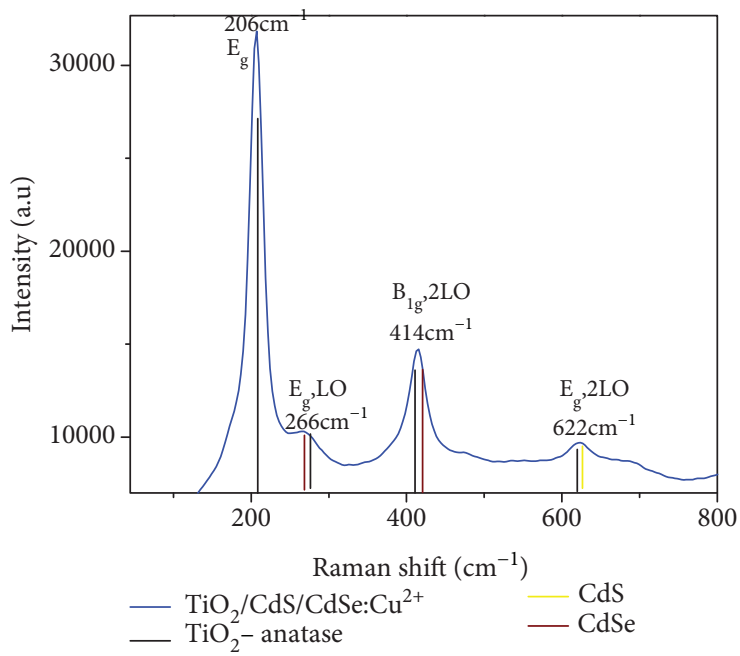

(h)

Figure 1: FESEM image at $100 \mathrm{~nm}(\mathrm{a}, \mathrm{d})$ and cross-section at $1 \mu \mathrm{m}(\mathrm{b}, \mathrm{e})$. EDX of CdSe:Mn ${ }^{2+}(20 \%)$ and CdSe:Cu${ }^{2+}(0.3 \%)(\mathrm{c}, \mathrm{f}) .(\mathrm{g}, \mathrm{h}) \mathrm{Raman}$ spectroscopy of CdSe:X-QDSSCs.

CdS, and CdSe: $\mathrm{Mn}^{2+}\left(\mathrm{Cu}^{2+}\right)$. It is immediately obvious that the Raman spectroscopy of $\mathrm{TiO}_{2} / \mathrm{CdS} / \mathrm{CdSe}: \mathrm{Mn}^{2+}$ electrode shows the modes at $144 \mathrm{~cm}^{-1}, 395 \mathrm{~cm}^{-1}, 515 \mathrm{~cm}^{-1}$, and $636 \mathrm{~cm}^{-1}$ positions corresponding to the $\mathrm{TiO}_{2}$ anatase [31]. Similarly, the above modes of $\mathrm{TiO}_{2}$ anatase in the Raman spectroscopy of $\mathrm{TiO}_{2} / \mathrm{CdS} / \mathrm{CdSe}: \mathrm{Cu}^{2+}$ electrode appear at $206 \mathrm{~cm}^{-1}, 266 \mathrm{~cm}^{-1}, 414 \mathrm{~cm}^{-1}$ and $622 \mathrm{~cm}^{-1}$ positions. It is immediately obvious that there was a shift of the modes towards the high frequency due to the increase of $\mathrm{CdSe}: \mathrm{Cu}^{2+}-\mathrm{TiO}_{2}$ associate compared to $\mathrm{CdSe}: \mathrm{Mn}^{2+}-\mathrm{TiO}_{2}$ associate. Besides, there are one Longitudinal-Optical (1LO) and 2LO modes of CdSe: $\mathrm{Mn}^{2+}$ Zinc Blende at $201 \mathrm{~cm}^{-1}$ and $395 \mathrm{~cm}^{-1}$ positions. However, the modes are shifted towards high frequency for $\mathrm{Cu}^{2+}$ ion-doped CdSe QDs. In addition, the 2LO mode of CdSe Cubic is shown in both Figures $1(\mathrm{~g})$ and $1(\mathrm{~h})$, but there was no $1 \mathrm{LO}$ mode.
This implies that $\mathrm{CdS}$, CdSe: $\mathrm{Cu}^{2+}\left(\mathrm{Mn}^{2+}\right)$ nanoparticles have absorbed on $\mathrm{TiO}_{2}$ films.

To determine the $E_{g}$ of the $\mathrm{TiO}_{2} / \mathrm{CdS} / \mathrm{CdSe}: \mathrm{Mn}^{2+}$ and $\mathrm{TiO}_{2} / \mathrm{CdS} / \mathrm{CdSe}: \mathrm{Cu}^{2+}$ electrodes, UV-Vis absorption measurements are carried out. By analysis of the absorption coefficients for the electrodes, optical energy gap can be estimated using Tauc plot of $(\alpha \mathrm{hv})^{2}$ versus (hv) and extrapolating of the linear portions of the curves to the energy axis according to [32]

$$
\alpha \mathrm{hv}=K\left(\mathrm{hv}-E_{g}\right)^{1 / 2}
$$

$\alpha$ is the absorption coefficient, which is determined by $\alpha \approx(1 / d) \ln \left(\left(1-R^{2}\right) / T\right)$ about $9.10^{4} \mathrm{~cm}^{-1}$ [33], where $d$ is 


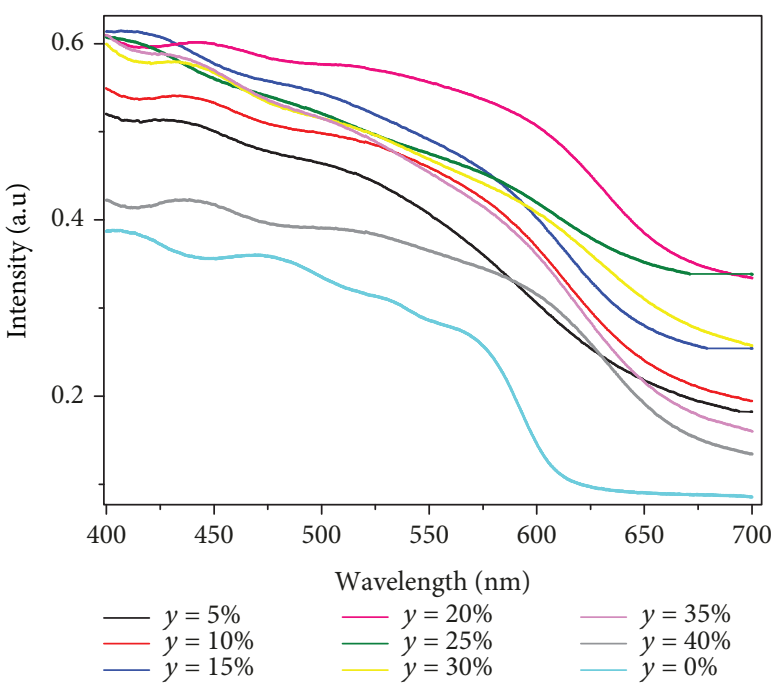

(a)

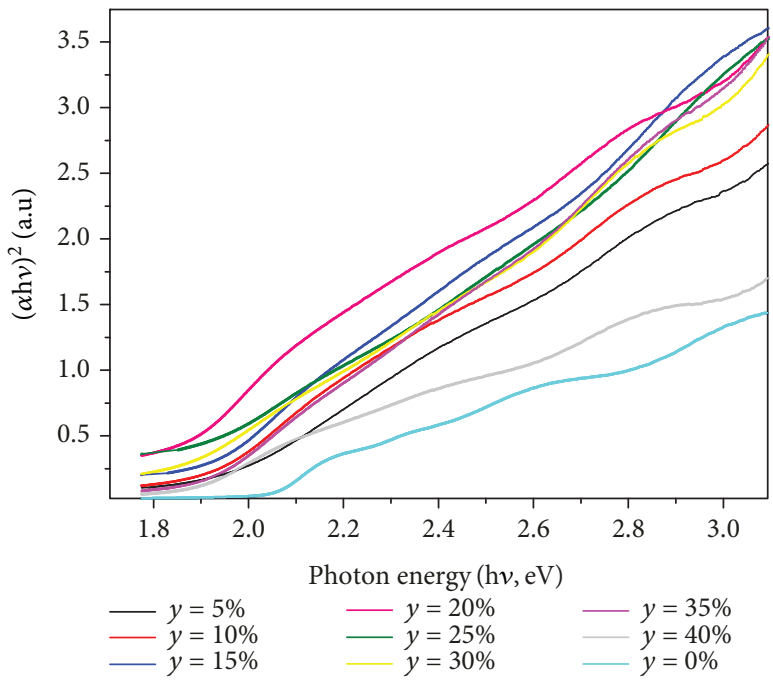

(c)

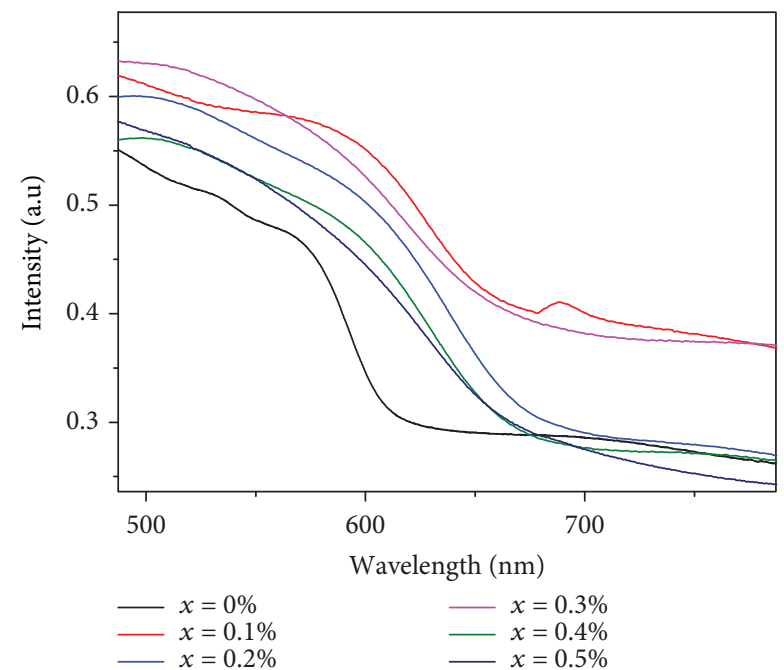

(b)

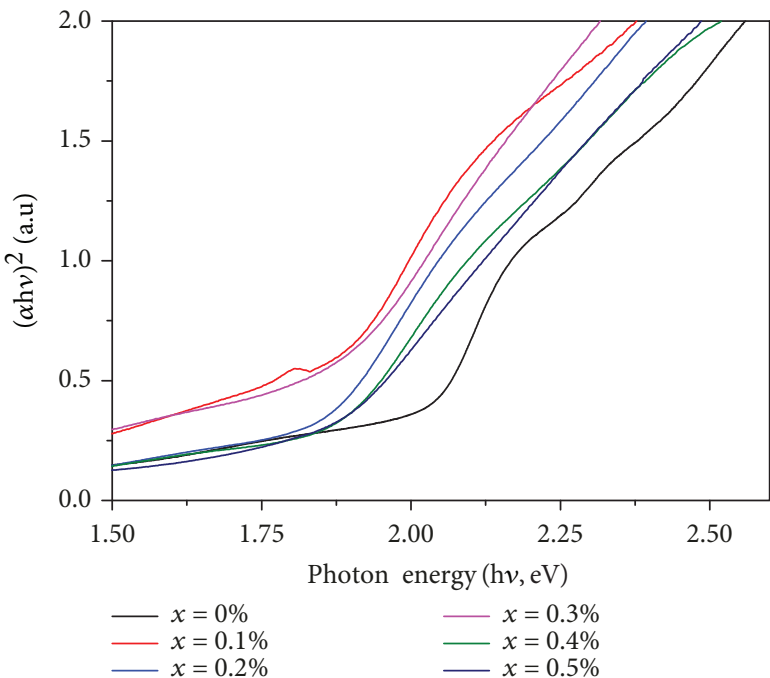

(d)

Figure 2: UV-Vis spectra of (a) CdSe(3) $\mathrm{Mn}^{2+}$ and (b) $\mathrm{CdSe}(3) \mathrm{Cu}^{2+} .(\alpha \mathrm{hv})^{2}$ vs. (hv) curves of (c) $\mathrm{CdSe}(3) \mathrm{Mn}^{2+}$ and (d) $\mathrm{CdSe}^{2}(3) \mathrm{Cu}^{2+} \mathrm{QDs}$.

the thickness of the film and $T$ is the transmittance; $R$ is the reflectance. $\mathrm{hv}$ is the photon energy, $E_{g}$ is the direct band gap energy, and $K$ is a constant (about $2.05910^{-2} \mathrm{~cm}^{-1}$ ) [33]. The Tauc plots are shown in Figure 2.

Moreover, the $\mathrm{CB}$ and $\mathrm{VB}$ of $\mathrm{CdS}$, CdSe nanoparticles can also be determined by Tauc equation. The $\mathrm{CB}$ and VB of materials can be calculated if the electron affinity energy and the ionization energy are known. Similarly, the CB and VB of CdS and CdSe can be determined by Tauc equation [34]. The calculated parameters are listed in Tables 1 and 2 .

Optical properties of undoped and doped photoanodes, which were prepared by SILAR method and calcined in a vacuum environment, were investigated by UV-Vis absorption spectra. Figures 2(a) and 2(b) show the UV-Vis absorption spectra of the photoelectrode with undoped $(x, y=0 \%)$ and doped concentration of $\mathrm{Mn}^{2+}$ ions from $5 \%$ to $40 \%$ and $\mathrm{Cu}^{2+}$ ions from $0.1 \%$ to $0.5 \%$. In general, there are two major
TABLE 1: The band gap, CB, and VB positions of $\mathrm{CdSe}: \mathrm{Cu}^{2+}$ are calculated by Tauc and UV-Vis spectra.

\begin{tabular}{lcccc}
\hline Materials & $E_{\mathrm{g}}(\mathrm{eV})$ & $X(\mathrm{eV})$ & $E_{\mathrm{CB}}(\mathrm{eV})$ & $E_{\mathrm{VB}}(\mathrm{eV})$ \\
\hline $\mathrm{CdSe}(3) \mathrm{Cu}^{2+}(x=0 \%)$ & 2.03 & 5.102 & -4.08 & -6.11 \\
$\mathrm{CdSe}(3) \mathrm{Cu}^{2+}(x=0.1 \%)$ & 1.75 & 4.913 & -4.04 & -5.79 \\
$\mathrm{CdSe}(3) \mathrm{Cu}^{2+}(x=0.2 \%)$ & 1.78 & 4.913 & -4.02 & -5.80 \\
$\mathrm{CdSe}(3) \mathrm{Cu}^{2+}(x=0.3 \%)$ & 1.73 & 4.913 & -4.05 & -5.78 \\
$\mathrm{CdSe}(3) \mathrm{Cu}^{2+}(x=0.4 \%)$ & 1.79 & 4.913 & -4.01 & -5.80 \\
$\mathrm{CdSe}(3) \mathrm{Cu}^{2+}(x=0.5 \%)$ & 1.78 & 4.913 & -4.02 & -5.80 \\
\hline
\end{tabular}

differences between UV-Vis absorption spectra of undoped films and doped films such as, firstly, there is a very sharp increase in absorption spectra intensity when we doped $\mathrm{Mn}^{2+}$ ions from $5 \%$ to $40 \%$ and $\mathrm{Cu}^{2+}$ ions from $0.1 \%$ to 
TABLE 2: The band gap, CB, and VB positions of CdSe:Mn ${ }^{2+}$ are calculated by Tauc and UV-Vis spectra.

\begin{tabular}{lcccc}
\hline Materials & $E_{\mathrm{g}}(\mathrm{eV})$ & $X(\mathrm{eV})$ & $E_{\mathrm{CB}}(\mathrm{eV})$ & $E_{\mathrm{VB}}(\mathrm{eV})$ \\
\hline $\mathrm{CdSe}(3) \mathrm{Mn}^{2+}(y=0 \%)$ & 2.03 & 5.10 & -4.08 & -6.11 \\
$\mathrm{CdSe}(3) \mathrm{Mn}^{2+}(y=5 \%)$ & 1.8 & 4.62 & -3.72 & -5.52 \\
$\mathrm{CdSe}(3) \mathrm{Mn}^{2+}(y=10 \%)$ & 1.81 & 4.62 & -3.71 & -5.52 \\
$\mathrm{CdSe}(3) \mathrm{Mn}^{2+}(y=15 \%)$ & 1.82 & 4.62 & -3.71 & -5.53 \\
$\mathrm{CdSe}(3) \mathrm{Mn}^{2+}(y=20 \%)$ & 1.75 & 4.62 & -3.74 & -5.49 \\
$\mathrm{CdSe}(3) \mathrm{Mn}^{2+}(y=25 \%)$ & 1.78 & 4.62 & -3.73 & -5.51 \\
$\mathrm{CdSe}(3) \mathrm{Mn}^{2+}(y=30 \%)$ & 1.8 & 4.62 & -3.72 & -5.52 \\
$\mathrm{CdSe}(3) \mathrm{Mn}^{2+}(y=35 \%)$ & 1.79 & 4.62 & -3.72 & -5.51 \\
$\mathrm{CdSe}(3) \mathrm{Mn}^{2+}(y=40 \%)$ & 1.8 & 4.62 & -3.72 & -5.52 \\
\hline
\end{tabular}

0.5\% on CdSe QDs. This implied that the presence of metal ion energy levels in the band gap of CdSe QDs causes an increase in the absorption of incoming photons [35]. This result will be explained in more detail when we determine the $\mathrm{CB}$ energy and the VB of both CdSe: $\mathrm{Mn}^{2+}$ and $\mathrm{CdSe}: \mathrm{Cu}^{2+}$ QDs. Secondly, there is a shift of the absorption peak in the red region compared to the undoped photoelectrodes (from $570 \mathrm{~nm}$ to $615 \mathrm{~nm}$ ) [36-38]. This is also understandable because of the change in band gap of CdSe QDs after doping; the CB position of CdSe QDs may be raised and its band gap may be narrowed. Figures 2(c) and 2(d) show the Tauc plot of $\mathrm{Mn}^{2+}$ ions from $5 \%$ to $40 \%$ and $\mathrm{Cu}^{2+}$ ions from $0.1 \%$ to $0.5 \%$ on CdSe QDs as shown in Tables 1 and 2. The band gap values of both CdSe:Mn ${ }^{2+}$ and CdSe: $\mathrm{Cu}^{2+} \mathrm{QDs}$ reduced compared to the band gap of pure CdSe QDs.

Figure 3 shows photocurrent density-voltage curves of QDSSCs based on the metal ion-doped photoanodes measured under AM 1.5, $100 \mathrm{~mW} / \mathrm{cm}^{2}$, and the photovoltaic parameters are listed in Table 3. The QDSSCs on undoped $\mathrm{TiO}_{2} / \mathrm{CdSe}$ films were measured with open circuit $\left(V_{\mathrm{OC}}=0.41 \mathrm{~V}\right), \mathrm{FF}$ (0.38), short-current density $\left(J_{\mathrm{SC}}=12.5 \mathrm{~mA}\right)$, and efficiency $(\eta=1.95 \%)$. In general, the QDSSCs based on CdSe: $\mathrm{Mn}^{2+}$ and CdSe: $\mathrm{Cu}^{2+}$ QDs have better performance compared to the QDSSCs based on undoped films. When doping, open-circuit parameters, short-circuit currents, and efficiency increase due to the conduction band position of CdSe: $\mathrm{Mn}^{2+}$ and CdSe: $\mathrm{Cu}^{2+} \mathrm{QDs}$, which is raised higher than that of $\mathrm{TiO}_{2}$ semiconductor and listed in Tables 1 and 2. Similar to the UV-Vis absorption spectra, there was a strong increase in efficiency of the QDSSCs from 1.95\% (with pure CdSe QDs) to $4.3 \%$ (with CdSe:Cu${ }^{2+}$ QDs) and 3.8\% (CdSe: $\mathrm{Mn}^{2+}$ QDs). The result of an increase performance is due to the effect of metal concentration impurities in CdSe QDs. This result is also explained by the calculation of $\mathrm{CB}$ energy levels, the $\mathrm{VB}$ of $\mathrm{TiO}_{2}$ semiconductor, $\mathrm{CdSe}: \mathrm{Mn}^{2+}$ and CdSe: $\mathrm{Cu}^{2+}$ QDs $[29,39]$. As we know, in the bulk material, the $\mathrm{CB}$ position of CdSe QDs $(-4.5 \mathrm{eV})$ is lower than the $\mathrm{CB}$ of $\mathrm{TiO}_{2}(-4.3 \mathrm{eV})$, which is difficult for excited electrons to move from CdSe QDs to $\mathrm{TiO}_{2}$ nanoparticles [27]. However, after doping, the $\mathrm{CB}$ energy of CdSe: $\mathrm{Mn}^{2+}$ and $\mathrm{CdSe}: \mathrm{Cu}^{2+}$ QDs is significantly increased from $-4.5 \mathrm{eV}$ to $-4.05 \mathrm{eV}$ (for
CdSe: $\mathrm{Cu}^{2+} \mathrm{QDs}$ ) and $-3.74 \mathrm{eV}$ (for CdSe:Mn ${ }^{2+} \mathrm{QDs}$ ), which is higher than the $\mathrm{CB}$ of $\mathrm{TiO}_{2}$ nanoparticles. Therefore, like a waterfall, electrons can easily move from CdSe:X QDs to $\mathrm{TiO}_{2}$ film. This result also causes an increase in current density from $12.5 \mathrm{~mA}$ to $20 \mathrm{~mA}$ (CdSe:Cu${ }^{2+} \mathrm{QDs}$ ) and $19 \mathrm{~mA}$ (CdSe: $\left.\mathrm{Mn}^{2+} \mathrm{QDs}\right)$.

Figures 4(a) and 4(b) are the EIS curves of photoanodes with the doped concentration of $\mathrm{Mn}^{2+}$ ions from 5\% to $40 \%$ and $\mathrm{Cu}^{2+}$ ions from $0.1 \%$ to $0.5 \%$ under one-sun illumination and open circuit of the device; the parameter values shown are in Tables 3 and 4. Basically, the EIS curves have two semicircles corresponding to the resistance at the surface of the polyelectrolyte/counter electrode (denoted as $R_{\mathrm{ct1}}$ ) and the diffuse resistance in the $\mathrm{TiO}_{2}$ film and $\mathrm{TiO}_{2} / \mathrm{CdSe}: \mathrm{X}$ surface (denoted as $R_{\mathrm{ct} 2}$ ) [40]. After measuring the EIS curve, we used Nova software to fit and obtain the circuit corresponding to each EIS curve. From the circuit obtained, we determined $R_{\mathrm{ct} 1}$ and $R_{\mathrm{ct} 2}$ resistances, respectively. The lifetime of the excited electron $\left(\tau_{n}\right)$ is determined by the formula $\tau_{n}=1 /\left(2 \pi f_{\min }\right)$, and the capacitance of QDSSCs $\left(C_{\mu}\right)$ is determined by $C_{\mu}=\tau_{n} / R_{\mathrm{ct} 2}$. The calculated values are presented in Tables 3 and 4 . In general, the QDSSCs based on $\mathrm{TiO}_{2} / \mathrm{CdSe}: \mathrm{Mn}^{2+}$ with the doped concentration from $5 \%$ to $40 \%$ and $\mathrm{TiO}_{2} / \mathrm{CdSe}: \mathrm{Cu}^{2+}$ with the doped concentration from $0.1 \%$ to $0.5 \%$ have sharply changed the photovoltaic, which causes the change of $R_{\mathrm{ct} 1}$ and $R_{\mathrm{ct} 2}$ resistance values, the capacitance, and the excited electron lifetime of CdSe:X QDs. In particular, the $R_{\mathrm{ct} 1}$ and $R_{\mathrm{ct} 2}$ resistances correspond to pure CdSe QDs recorded approximately $630.5 \Omega$ and $194.8 \Omega$; they are much higher than both the $R_{\mathrm{ct} 1}(254.4 \Omega)$ and $R_{\mathrm{ct} 2}(8.68 \Omega)$ resistances with the $\mathrm{Cu}^{2+}$-doped concentration from $0.1 \%$ to $0.5 \%$ and the $R_{\mathrm{ct} 1}(204.5 \Omega)$ and $R_{\mathrm{ct} 2}(24.65 \Omega)$ resistances with the $\mathrm{Mn}^{2+}$-doped concentration from $10 \%$ to $40 \%$, while the excited electron lifetime and capacitances of QDSSCs are much lower [29]. This result implies that $\mathrm{Cu}^{2+}$ and $\mathrm{Mn}^{2+}$ doping into CdSe QDs can cause a decrease in diffusion resistance in $\mathrm{TiO}_{2}$ films and surfaces. Furthermore, the cause of the increase in performance may be due to the increase in the $\mathrm{CB}$ position of the CdSe:X QDs, which is higher than that of the $\mathrm{TiO}_{2}$ conduction band. In addition, the energy level of metal ion appears in the band gap of CdSe QDs, which reduces the band gap energy of CdSe:X QDs. This result is evidenced by the shift and an increase in the intensity of the UV-Vis absorption spectra (Figure 2). From the above reasons, we can show an increase in the current density and decrease the $R_{\mathrm{ct} 2}$ resistance of the device.

\section{Conclusions}

The QDSSCs based on $\mathrm{TiO}_{2} / \mathrm{CdS} / \mathrm{CdSe}(3) \mathrm{Cu}^{2+}(x)$ with $x$ from $0 \%$ to $0.5 \%$ and $\mathrm{TiO}_{2} / \mathrm{CdS} / \mathrm{CdSe}(3) \mathrm{Mn}^{2+}(y)$ with $y$ from $0 \%$ to $40 \%$ were successfully fabricated by the SILAR method. The $\mathrm{TiO}_{2} / \mathrm{CdS} / \mathrm{CdSe}(3) \mathrm{Cu}^{2+}(x)$ cosensitized solar cells demonstrated better performance $(4.3 \%)$ than the $\mathrm{TiO}_{2} / \mathrm{CdS} /$ $\mathrm{CdSe}(3) \mathrm{Mn}^{2+}(y)(3.8 \%)$ and $\mathrm{TiO}_{2} / \mathrm{CdS}(3) / \mathrm{CdSe}(3)(1.96 \%)$. This result is a cause of the light harvesting for producing excitons, facility fast electron transfer at $\mathrm{TiO} 2 / \mathrm{CdS} / \mathrm{CdSe}: \mathrm{Mn}^{2+}$ 


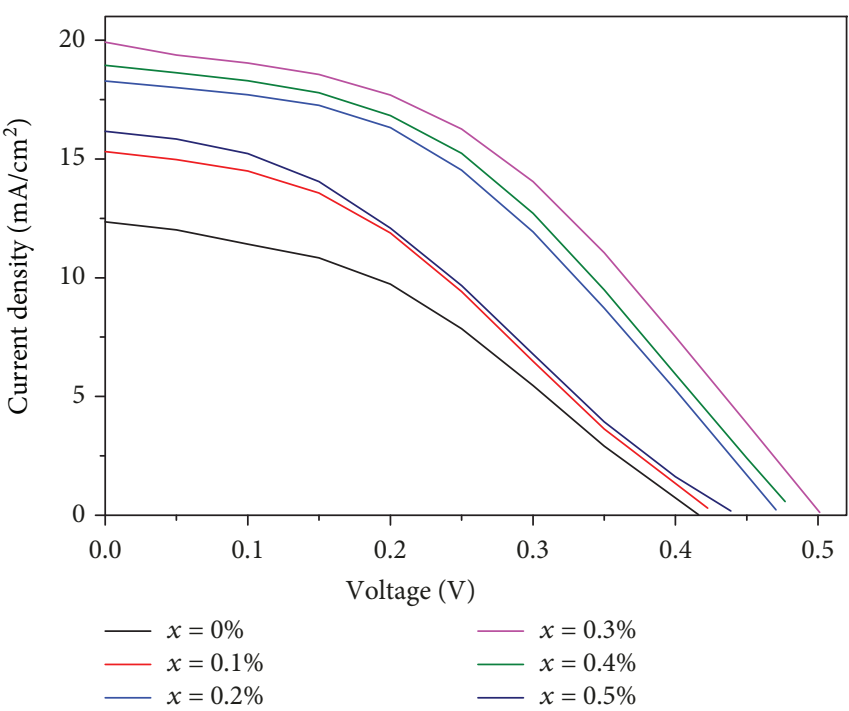

(a)

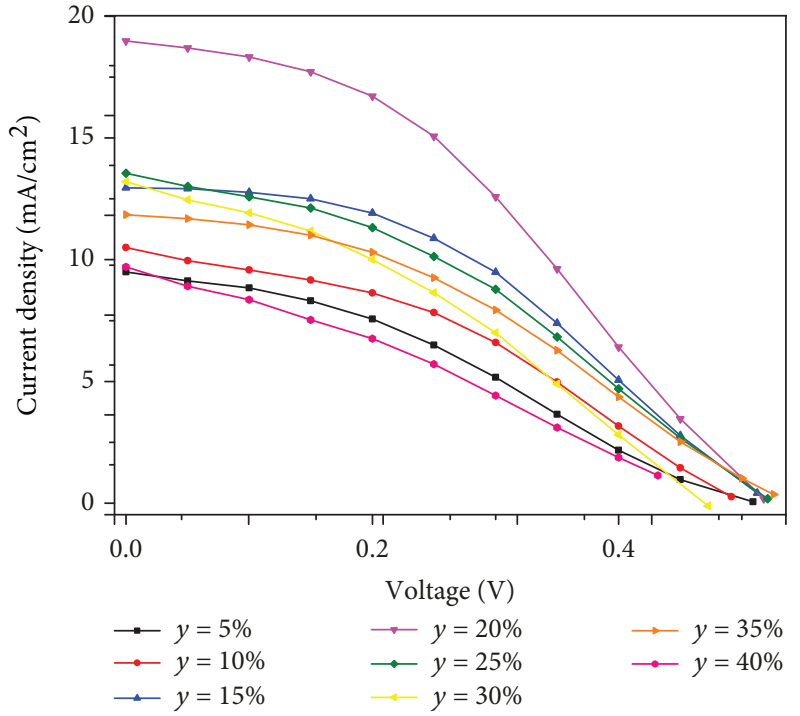

(b)

FIGURE 3: Photocurrent density-voltage $(J-V)$ curves of (a) CdSe:Cu${ }^{2+}-$ QDSSCs and (b) CdSe:Mn ${ }^{2+}{ }_{-}$QDSSCs.

TABLe 3: The values of $J-V$ curves and electrochemical impedance spectra with $x$ from $0 \%$ to $0.5 \%$.

\begin{tabular}{lcccccccc}
\hline QDSSCs & $J_{\mathrm{SC}}\left(\mathrm{mA} / \mathrm{cm}^{2}\right)$ & $\mathrm{FF}$ & $V_{\mathrm{OC}}(\mathrm{V})$ & $\eta(\%)$ & $R_{\mathrm{ct} 1}(\Omega)$ & $R_{\mathrm{ct} 2}(\Omega)$ & $C_{\mu}(\mu \mathrm{F})$ & $\tau_{n}(\mathrm{~ms})$ \\
\hline $\mathrm{CdSe}: \mathrm{Cu}^{2+}(x=0 \%)$ & 12.5 & 0.38 & 0.41 & 1.95 & 630.5 & 194.8 & 12.25 & 58.7 \\
$\mathrm{CdSe}: \mathrm{Cu}^{2+}(x=0.1 \%)$ & 15.32 & 0.36 & 0.43 & 2.38 & 542.5 & 94.48 & 72.66 & 77.2 \\
$\mathrm{CdSe}: \mathrm{Cu}^{2+}(x=0.2 \%)$ & 18.28 & 0.42 & 0.47 & 3.63 & 389.8 & 59.85 & 86.72 & 82.3 \\
$\mathrm{CdSe}: \mathrm{Cu}^{2+}(x=0.3 \%)$ & 20.0 & 0.42 & 0.50 & 4.3 & 254.4 & 8.68 & 160.5 & 83.6 \\
$\mathrm{CdSe}: \mathrm{Cu}^{2+}(x=0.4 \%)$ & 18.9 & 0.42 & 0.49 & 3.81 & 330.5 & 22.71 & 156.2 & 72.9 \\
$\mathrm{CdSe}: \mathrm{Cu}^{2+}(x=0.5 \%)$ & 16.17 & 0.34 & 0.44 & 2.42 & 560.6 & 138.9 & 139.7 & 83.2 \\
\hline
\end{tabular}

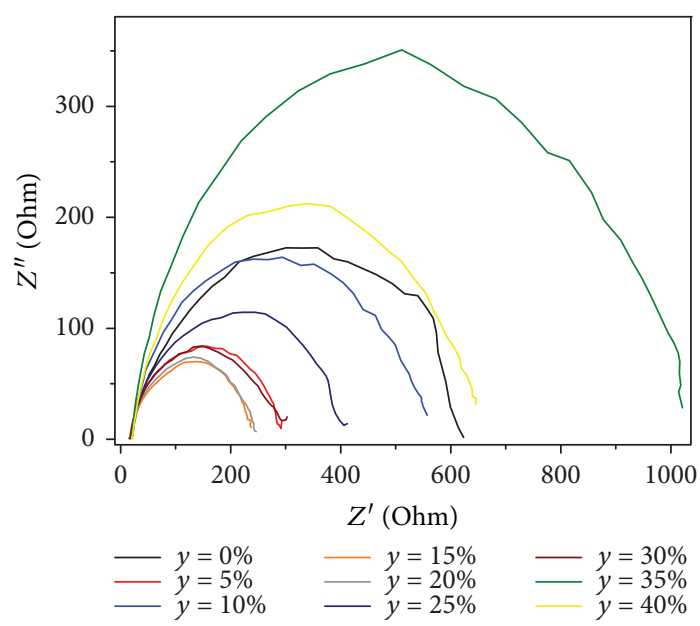

(a)

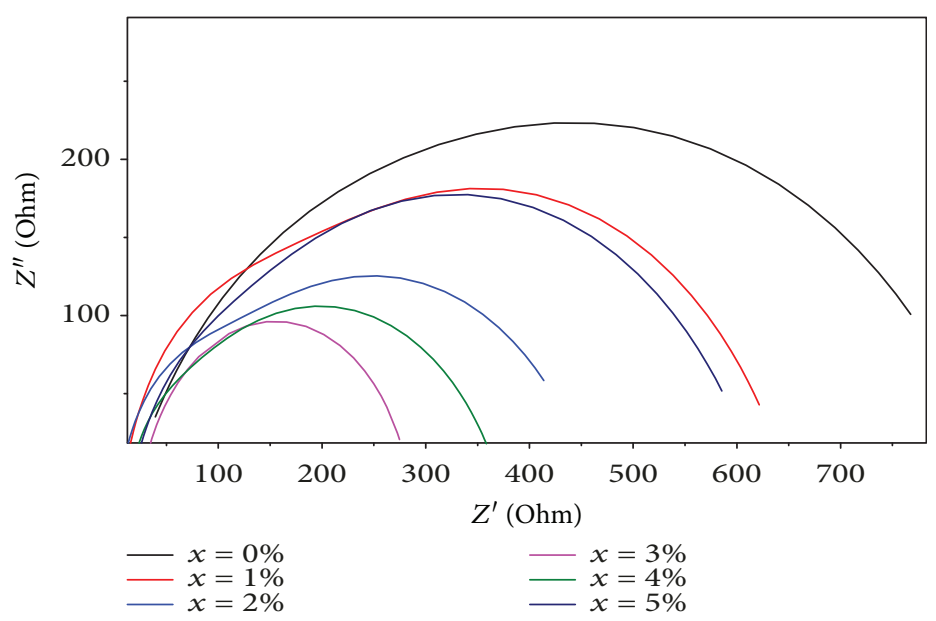

(b)

FIgURE 4: Nyquist curves of QDSSCs. (a) $\mathrm{Mn}^{2+}$ concentration changing from $0 \%$ to $40 \%$. (b) $\mathrm{Cu}^{2+}$ concentration changing from $0 \%$ to $0.5 \%$.

$\left(\mathrm{Cu}^{2+}\right)$ interfaces, and the reduced recombination in the QDSSCs as the concentration of $\mathrm{Cu}^{2+}\left(\mathrm{Mn}^{2+}\right)$ doped on the CdSe nanoparticles. In addition, the optical properties, the direct optical energy gap, and both the CB and VB levels of the compositional CdS, CdSe: $\mathrm{Cu}^{2+}$ and CdSe: $\mathrm{Mn}^{2+}$ were estimated by the theory of Tauc and discussed details. This theory 
TABLe 4: The values of $J-V$ curves and electrochemical impedance spectra with $y$ from $0 \%$ to $40 \%$.

\begin{tabular}{lcccccccc}
\hline QDSSCs & $J_{\mathrm{SC}}\left(\mathrm{mA} / \mathrm{cm}^{2}\right)$ & $\mathrm{FF}$ & $V_{\mathrm{OC}}(\mathrm{V})$ & $\eta(\%)$ & $R_{\mathrm{ct} 1}(\Omega)$ & $R_{\mathrm{ct} 2}(\Omega)$ & $C_{\mu}(\mu \mathrm{F})$ & $\tau_{n}(\mathrm{~ms})$ \\
\hline CdSe: $\mathrm{Mn}^{2+}(y=0 \%)$ & 12.5 & 0.38 & 0.41 & 1.95 & 630.5 & 194.8 & 12.25 & 58.7 \\
CdSe: $\mathrm{Mn}^{2+}(y=5 \%)$ & 9.50 & 0.33 & 0.51 & 1.62 & 388 & 156.8 & 56.14 & 58.5 \\
CdSe: $\mathrm{Mn}^{2+}(y=10 \%)$ & 10.50 & 0.37 & 0.50 & 1.97 & 126.3 & 97.68 & 51.57 & 61.5 \\
CdSe: $\mathrm{Mn}^{2+}(y=15 \%)$ & 12.95 & 0.41 & 0.52 & 2.84 & 338.6 & 53.34 & 99.34 & 63.9 \\
CdSe: $\mathrm{Mn}^{2+}(y=20 \%)$ & 19.0 & 0.38 & 0.52 & 3.8 & 204.5 & 24.65 & 139.1 & 69.2 \\
CdSe: $\mathrm{Mn}^{2+}(y=25 \%)$ & 13.55 & 0.36 & 0.52 & 2.63 & 203.4 & 75.03 & 83.55 & 59.2 \\
CdSe: $\mathrm{Mn}^{2+}(y=30 \%)$ & 13.20 & 0.34 & 0.46 & 2.16 & 801.8 & 206.2 & 72.23 \\
CdSe: $\mathrm{Mn}^{2+}(y=35 \%)$ & 11.84 & 0.37 & 0.53 & 2.37 & 444.9 & 190.7 & 71.33 \\
CdSe: $\mathrm{Mn}^{2+}(y=40 \%)$ & 9.71 & 0.30 & 0.47 & 1.42 & 780.1 & 566.7 & 55.87 & 59.2 \\
\hline
\end{tabular}

is useful for us to understand the alignment energy structure of the compositions in electrodes, in particular, the $\mathrm{CB}$ and VB levels of CdS, CdSe:Cu${ }^{2+}$, and CdSe: $\mathrm{Mn}^{2+}$ nanoparticles. As a result, there is a rise or drop of the $\mathrm{CB}$ and VB levels when $\mathrm{Cu}^{2+}\left(\mathrm{Mn}^{2+}\right)$ content was changed.

\section{Data Availability}

The data used to support the findings of this study are available from the corresponding author upon request.

\section{Conflicts of Interest}

The authors declare no competing interests.

\section{Acknowledgments}

The authors would like to thank University of Science, Viet Nam National University Ho Chi Minh City, Vietnam.

\section{Supplementary Materials}

Supplemental Figure 1: FESEM image at $100 \mathrm{~nm}(\mathrm{a}, \mathrm{d})$, cross section at $1 \mu \mathrm{m}(\mathrm{b}, \mathrm{e})$, and EDX of CdSe: $\mathrm{Mn}^{2+}(20 \%)$ and CdSe: $\mathrm{Cu}^{2+}(0.3 \%)$ (c, f). (g, h) Raman spectroscopy of CdSe:X-QDSSCs. The morphology of preparing as-photoelectrodes with $20 \%$ of $\mathrm{Mn}^{2+}$ and $0.3 \%$ of $\mathrm{Cu}^{2+}$ could be obtained from FESEM. In addition, the compositions and structure of films could be investigated from EDX and Raman spectra. In general, these are the main data sets, which provided all information about the morphology, sizes, and thickness of a sandwich layer and structure of preparing as-photoelectrodes. Supplemental Figure 2: UV-Vis spectra of (a) $\mathrm{CdSe}(3) \mathrm{Mn}^{2+}$ and (b) $\mathrm{CdSe}(3) \mathrm{Cu}^{2+}$. ( $\alpha$ hv) 2 vs. (hv) curves of (c) $\mathrm{CdSe}(3) \mathrm{Mn}^{2+}$ and (d) $\mathrm{CdSe}(3) \mathrm{Cu}^{2+}$ QDs. This is the supplementary material which supports for us to determine the band gap of sample as getting the peak of UV-Vis spectra, in particular, calculate the conduction band and valence band of material. Supplemental Figure 3: photocurrent density-voltage (J-V) curves of (a) CdSe:Cu${ }^{2+}$-QDSSCs and (b) CdSe: $\mathrm{Mn}^{2+}$-QDSSCs. The performance of the quantum dot-sensitized solar cells could be obtained from the photocurrent density-voltage curves. These results support the discussion from the electrochemical impedance spectra. Supplemental Figure 4: Nyquist curves of QDSSCs. (a) $\mathrm{Mn}^{2+}$ concentration changing from $0 \%$ to $40 \%$ and (b) $\mathrm{Cu}^{2+}$ concentration changing from $0 \%$ to $0.5 \%$. The data set obtained from the electrochemical impedance spectra such as Nyquist curves, Bode phase. They are used to determine resistance dynamic, lifetime, and capacitances of the photoelectrodes to correlate with the shift of excited electrons from quantum dots to $\mathrm{TiO} 2$ nanoparticles, the diffusion of electrons. (Supplementary Materials)

\section{References}

[1] S. Ruhle, M. Shalom, and A. Zaban, "Quantum-dot-sensitized solar cells," ChemPhysChem, vol. 11, no. 11, pp. 2290-2304, 2010.

[2] C. Zhi and L. Dai, Eds., Flexible Energy Conversion and Storage Devices, John Wiley \& Sons, 2018.

[3] P. Yu, K. Zhu, A. G. Norman, S. Ferrere, A. J. Frank, and A. J. Nozik, "Nanocrystalline $\mathrm{TiO}_{2}$ solar cells sensitized with InAs quantum dots," The Journal of Physical Chemistry B, vol. 110, no. 50, pp. 25451-25454, 2006.

[4] Z. A. Peng and X. Peng, "Formation of high-quality CdTe, CdSe, and CdS nanocrystals using $\mathrm{CdO}$ as precursor," Journal of the American Chemical Society, vol. 123, no. 1, pp. 183-184, 2001.

[5] M. C. Beard, "Multiple exciton generation in semiconductor quantum dots," Journal of Physical Chemistry Letters, vol. 2, no. 11, pp. 1282-1288, 2011.

[6] E. H. Sargent, "Infrared quantum dots," Advanced Materials, vol. 17, no. 5, pp. 515-522, 2005.

[7] J. Fang, J. Wu, X. Lu, Y. Shen, and Z. Lu, "Sensitization of nanocrystalline $\mathrm{TiO}_{2}$ electrode with quantum sized CdSe and ZnTcPc molecules," Chemical Physics Letters, vol. 270, no. 1-2, pp. 145-151, 1997.

[8] W. Lee, W.-C. Kwak, S. K. Min et al., "Spectral broadening in quantum dots-sensitized photoelectrochemical solar cells based on CdSe and Mg-doped CdSe nanocrystals," Electrochemistry Communications, vol. 10, no. 11, pp. 1699-1702, 2008.

[9] J. Tao, Z. Sun, Y. Cheng et al., "Enhanced photoelectrochemical properties of nanocrystalline $\mathrm{TiO}_{2}$ electrode by surface sensitization with $\mathrm{Cu}_{\mathrm{x}} \mathrm{O}$ quantum dots," Scientific Reports, vol. 7, no. 1, p. 5291, 2017.

[10] L. M. Peter, D. J. Riley, E. J. Tull, and K. G. U. Wijayantha, "Photosensitization of nanocrystalline $\mathrm{TiO}_{2}$ by self-assembled layers of CdS quantum dots," Chemical Communications, no. 10, pp. 1030-1031, 2002. 
[11] Z. L. Wang and W. Wu, "Nanotechnology-enabled energy harvesting for self-powered micro-/nanosystems," Angewandte Chemie International Edition, vol. 51, no. 47, pp. 11700-11721, 2012.

[12] J. Chen, D. W. Zhao, J. L. Song et al., "Directly assembled CdSe quantum dots on $\mathrm{TiO}_{2}$ in aqueous solution by adjusting $\mathrm{pH}$ value for quantum dot sensitized solar cells," Electrochemistry Communications, vol. 11, no. 12, pp. 22652267, 2009.

[13] X.-Y. Yu, B.-X. Lei, D.-B. Kuang, and C.-Y. Su, "High performance and reduced charge recombination of CdSe/CdS quantum dot-sensitized solar cells," Journal of Materials Chemistry, vol. 22, no. 24, pp. 12058-12063, 2012.

[14] S. W. Jung, J.-H. Kim, H. Kim, C.-J. Choi, and K.-S. Ahn, “ZnS overlayer on in situ chemical bath deposited CdS quantum dot-assembled $\mathrm{TiO}_{2}$ films for quantum dot-sensitized solar cells," Current Applied Physics, vol. 12, no. 6, pp. 1459-1464, 2012.

[15] M. Shalom, J. Albero, Z. Tachan, E. Martínez-Ferrero, A. Zaban, and E. Palomares, "Quantum dot-dye bilayer-sensitized solar cells: breaking the limits imposed by the low absorbance of dye monolayers," The Journal of Physical Chemistry Letters, vol. 1, no. 7, article 1134, 1138 pages, 2010.

[16] T. Zewdu, J. N. Clifford, J. P. Hernández, and E. Palomares, "Photo-induced charge transfer dynamics in efficient $\mathrm{TiO}_{2} / \mathrm{CdS} / \mathrm{CdSe}$ sensitized solar cells," Energy \& Environmental Science, vol. 4, no. 11, p. 4633, 2011.

[17] J. Jiao, Z.-J. Zhou, W.-H. Zhou, and S.-X. Wu, "CdS and PbS quantum dots co-sensitized $\mathrm{TiO}_{2}$ nanorod arrays with improved performance for solar cells application," Materials Science in Semiconductor Processing, vol. 16, no. 2, pp. 435440, 2013.

[18] Y.-J. Shen and Y.-L. Lee, “Assembly of CdS quantum dots onto mesoscopic $\mathrm{TiO}_{2}$ films for quantum dot-sensitized solar cell application," Nanotechnology, vol. 19, no. 4, article 045602, 2008.

[19] W. W. Yu, L. Qu, W. Guo, and X. Peng, "Experimental determination of the extinction coefficient of CdTe, CdSe, and CdS nanocrystals," Chemistry of Materials, vol. 15, no. 14, pp. 2854-2860, 2003.

[20] F. Zhuge, X. Li, X. Gao, X. Gan, and F. Zhou, "Synthesis of stable amorphous $\mathrm{Cu}_{2} \mathrm{~S}$ thin film by successive ion layer adsorption and reaction method," Materials Letters, vol. 63, no. 8, pp. 652-654, 2009.

[21] S.-Q. Fan, R.-J. Cao, Y.-X. Xi, M. Gao, M.-D. Wang, and D.-H. Kima, "CdSe quantum dots as co-sensitizers of organic dyes in solar cells for red-shifted light harvesting," Optoelectronics and Advanced Materials - Rapid Communications, vol. 3, no. 10, pp. 1027-1033, 2009.

[22] B. Fang, M. Kim, S. Q. Fan et al., "Facile synthesis of open mesoporous carbon nanofibers with tailored nanostructure as a highly efficient counter electrode in CdSe quantum-dotsensitized solar cells," Journal of Materials Chemistry, vol. 21, no. 24, pp. 8742-8748, 2011.

[23] G. Chmid, Nanoparticles: From Theory to Application, Wiley-VCH, 2014.

[24] V. S. Raut, C. D. Lokhande, and V. V. Killedar, "Studies on effect of $\mathrm{pH}$ on structural, optical and morphological properties of chemisynthesized CdSe grains," International Journal of Engineering, vol. 10, no. 1, p. 2017, 2017.
[25] S. Giménez, I. Mora-Seró, L. Macor et al., "Improving the performance of colloidal quantum-dot-sensitized solar cells," Nanotechnology, vol. 20, no. 29, article 295204, 2009.

[26] V. Gonzalez-Pedro, X. Xu, I. Mora-Sero, and J. Bisquert, "Modeling high-efficiency quantum dot sensitized solar cells," ACS Nano, vol. 4, no. 10, pp. 5783-5790, 2010.

[27] M. Gratzel, "Photoelectrochemical cells," Nature, vol. 414, no. 6861 , pp. 338-344, 2001.

[28] M. Gratzel, "Dye-sensitized solar cells," Journal of Photochemistry and Photobiology C: Photochemistry Reviews, vol. 4, no. 2, pp. 145-153, 2003.

[29] K. Veerathangam, M. S. Pandian, and P. Ramasamy, "Photovoltaic performance of Ag-doped CdS quantum dots for solar cell application," Materials Research Bulletin, vol. 94, pp. 371377, 2017.

[30] D. H. Phuc and H. T. Tung, "The effect of thickness on the performance of CdSe: $\mathrm{Cu}^{2+}$-quantum dot-sensitized solar cells," Applied Physics A, vol. 124, no. 11, p. 731, 2018.

[31] J. Y. Kim, S. B. Choi, J. H. Noh et al., "Synthesis of CdSe-TiO nanocomposites and their applications to $\mathrm{TiO}_{2}$ sensitized solar cells," Langmuir, vol. 25, no. 9, pp. 5348-5351, 2009.

[32] Y.-L. Xie, "Enhanced photovoltaic performance of hybrid solar cell using highly oriented CdS/CdSe-modified $\mathrm{TiO}_{2}$ nanorods," Electrochimica Acta, vol. 105, pp. 137-141, 2013.

[33] A. Sharma, N. Mehta, and A. Kumar, "Dielectric relaxation in $\mathrm{Se}_{80-x} \mathrm{Te}_{20} \mathrm{Sn}_{x}$ chalcogenide glasses," Journal of Materials Science, vol. 46, no. 13, pp. 4509-4516, 2011.

[34] P. Mandal, S. S. Talwar, S. S. Major, and R. S. Srinivasa, "Orange-red luminescence from $\mathrm{Cu}$ doped $\mathrm{CdS}$ nanophosphor prepared using mixed Langmuir-Blodgett multilayers," Journal of Chemical Physics, vol. 128, no. 11, article 114703, 2008.

[35] S. B. Singh, M. V. Limaye, N. P. Lalla, and S. K. Kulkarni, "Copper-ion-induced photoluminescence tuning in CdSe nanoparticles," Journal of Luminescence, vol. 128, no. 12, pp. 1909-1912, 2008.

[36] B. B. Srivastava, S. Jana, and N. Pradhan, "Doping Cu in semiconductor nanocrystals: some old and some new physical insights," Journal of the American Chemical Society, vol. 133, no. 4, pp. 1007-1015, 2011.

[37] M. P. A. Muthalif, Y. S. Lee, C. D. Sunesh, H. J. Kim, and Y. Choe, "Enhanced photovoltaic performance of quantum dot-sensitized solar cells with a progressive reduction of recombination using $\mathrm{Cu}$-doped $\mathrm{CdS}$ quantum dots," Applied Surface Science, vol. 396, pp. 582-589, 2017.

[38] N. S. Karan, D. D. Sarma, R. M. Kadam, and N. Pradhan, "Doping transition metal ( $\mathrm{Mn}$ or $\mathrm{Cu}$ ) ions in semiconductor nanocrystals," Journal of Physical Chemistry Letters, vol. 1, no. 19, pp. 2863-2866, 2010.

[39] K. Veerathangam, M. Senthil Pandian, and P. Ramasamy, "Photovoltaic performance of $\mathrm{Pb}$-doped $\mathrm{CdS}$ quantum dots for solar cell application," Materials Letters, vol. 220, pp. 7477, 2018.

[40] O. Amiri, M. Salavati-Niasari, and M. Farangi, "Enhancement of dye-sensitized solar cells performance by core shell Ag@organic (organic=2-nitroaniline, PVA, 4-choloroaniline and PVP): effects of shell type on photocurrent," Electrochimica Acta, vol. 153, pp. 90-96, 2015. 

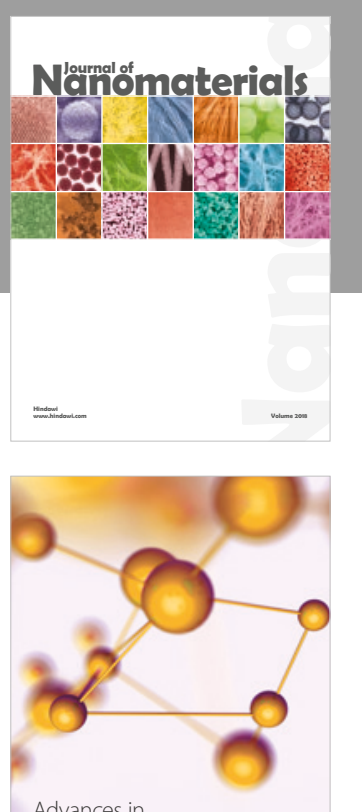

Physical Chemistry
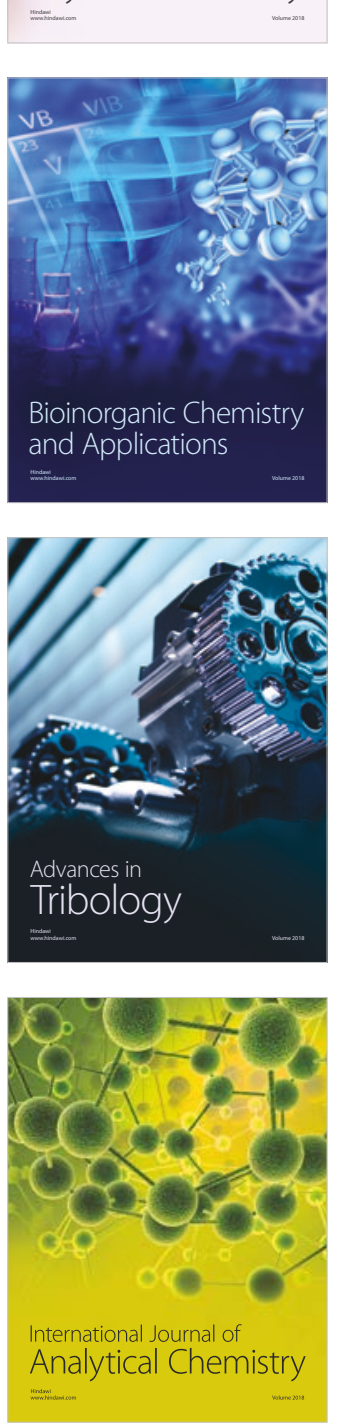

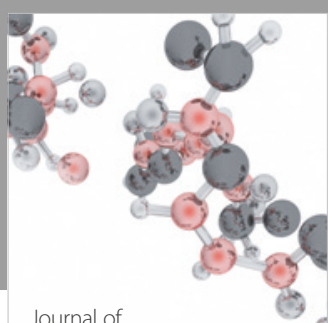

Analytical Methods

in Chemistry

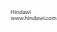

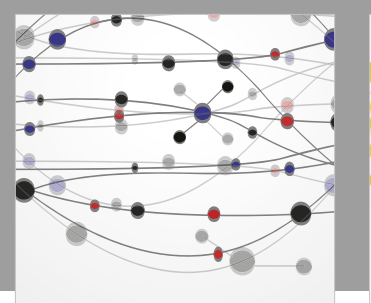

The Scientific World Journal

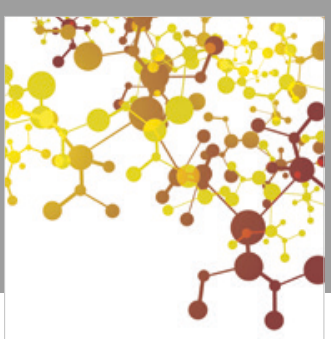

Journal of

Applied Chemistry
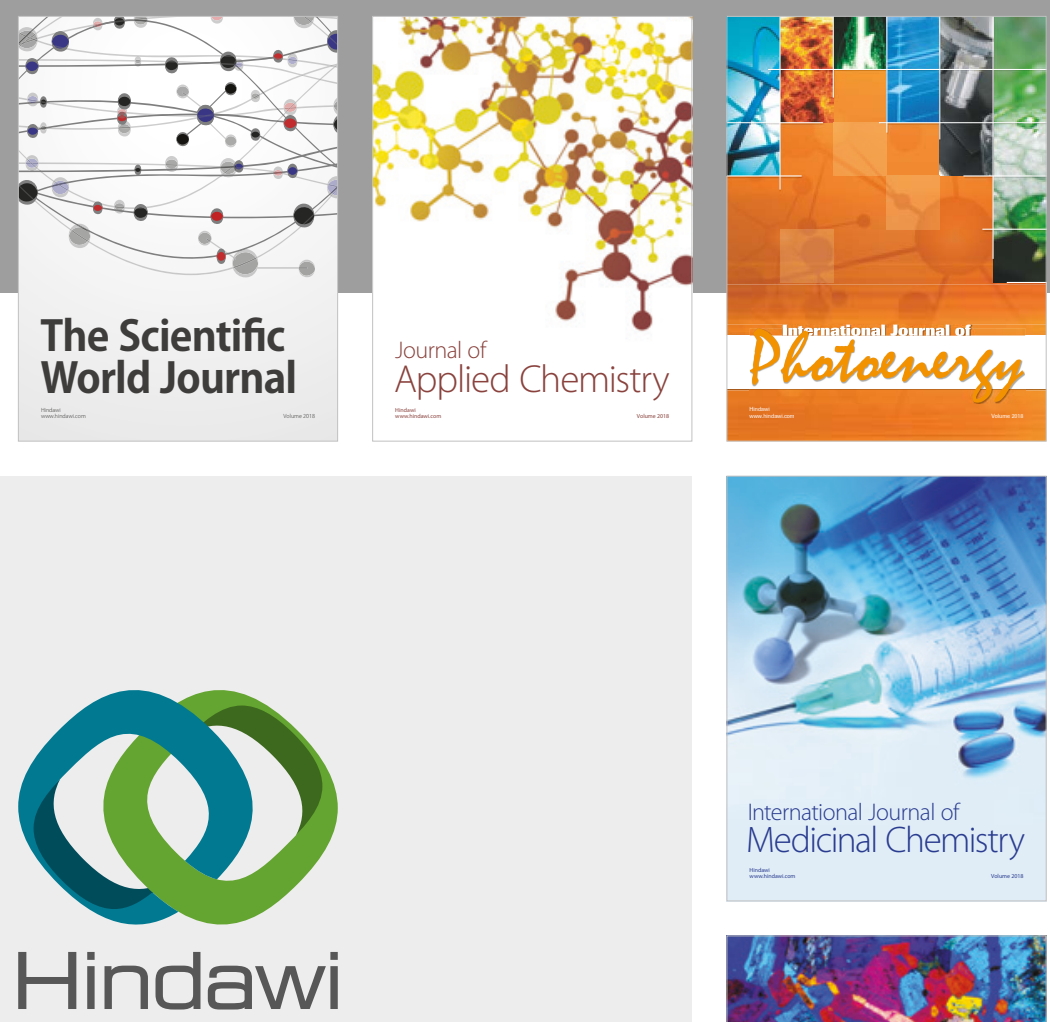

Submit your manuscripts at

www.hindawi.com
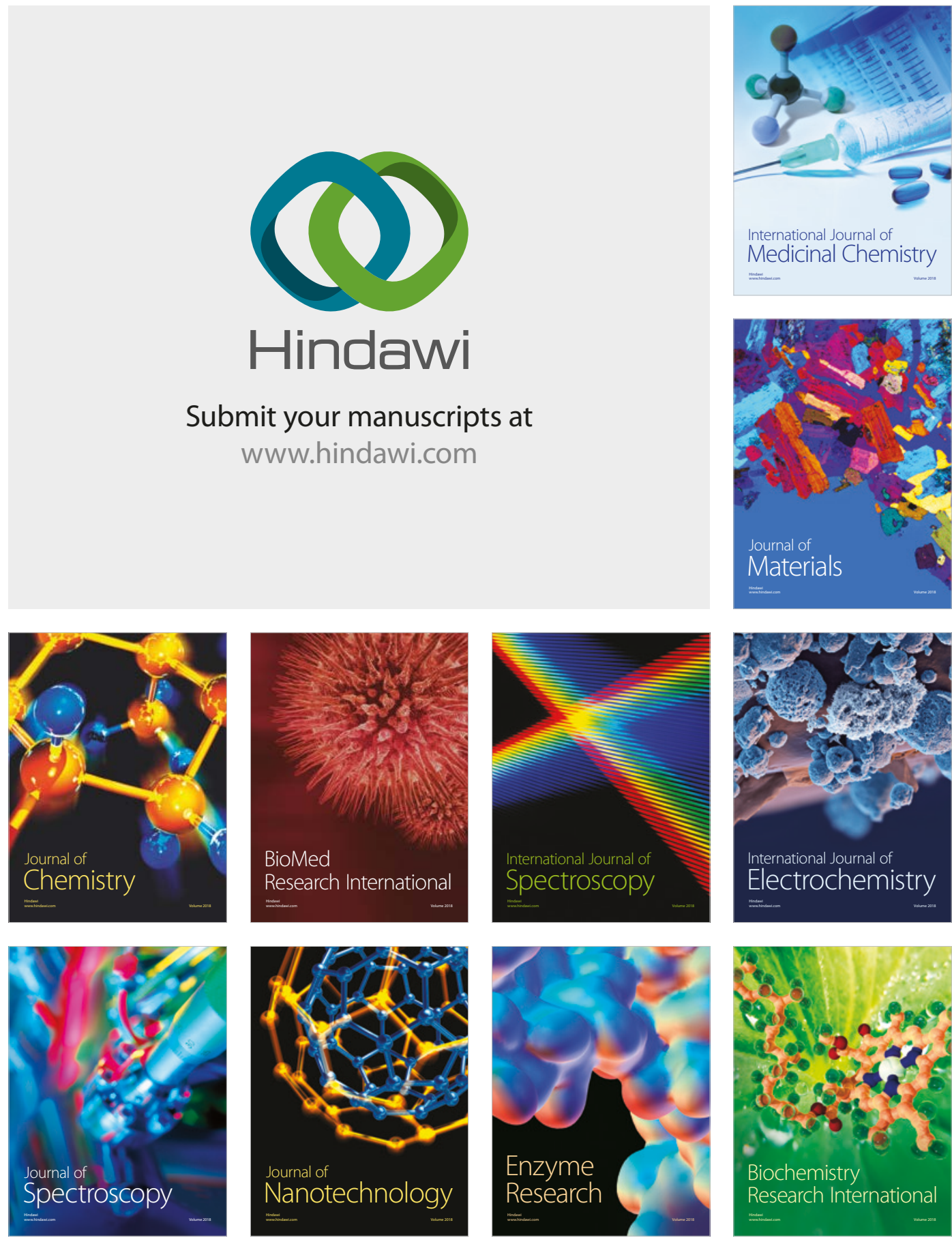
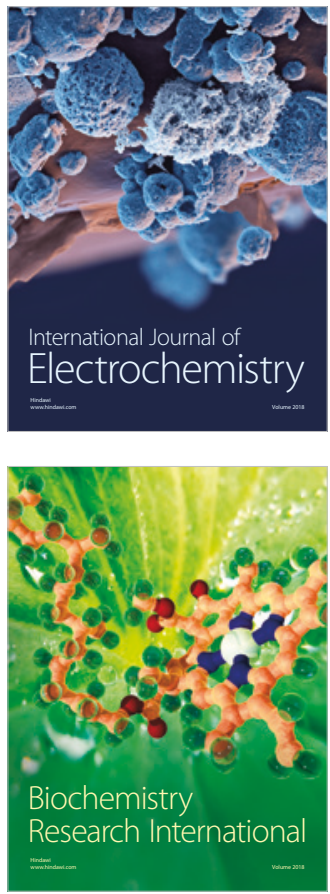